\title{
A shift in the spatial pattern of Iberian droughts during the 17th century
}

\author{
F. Domínguez-Castro ${ }^{1}$, R. García-Herrera ${ }^{1}$, P. Ribera ${ }^{2}$, and M. Barriendos ${ }^{3}$ \\ ${ }^{1}$ Departamento Física de la Tierra II, Facultad de Ciencias Físicas, Universidad Complutense de Madrid, Madrid, Spain \\ ${ }^{2}$ Departamento de Sistemas Físicos, Químicos y Naturales, Universidad Pablo de Olavide, Sevilla, Spain \\ ${ }^{3}$ Department of Modern History, University of Barcelona, Spain
}

Received: 18 May 2010 - Published in Clim. Past Discuss.: 7 June 2010

Revised: 7 August 2010 - Accepted: 23 August 2010 - Published: 6 September 2010

\begin{abstract}
In this paper, series of drought occurrence and drought extension in the Iberian Peninsula are constructed for the $1600-1750$ period from seven rogation series. These rogation ceremony records come from Bilbao, Catalonia, Zamora, Zaragoza, Toledo, Murcia and Seville. They are distributed across the Peninsula and include the areas with the most characteristic Iberian climate types, influenced by the Atlantic and the Mediterranean conditions, described from modern data. A seasonal division of the series shows that spring is a critical season for rogation series in most of Iberia, being Bilbao the only site were the highest number of rogations is detected for a different season. The annual analysis of the series shows a dramatic difference between the first half of the 17th century when droughts are characterized by its local character; and the rest of the period, when they affect to broader regions or even to the whole Peninsula. The analysis of spring series confirms the existence of the two periods detected in the annual analysis. Finally, secondary documentary sources are used to further characterise the two most extended droughts in the period, 1664 and 1680, and to verify the extension of the areas affected by droughts recorded through rogation series.
\end{abstract}

\section{Introduction}

Drought has been exhaustively analysed in Iberia during the recent years (Pérez-Cueva and Escrivá, 1982; Martín-Vide and Gomez, 1999; Estrela et al., 2000; Olcina, 2001; Gil Ol-

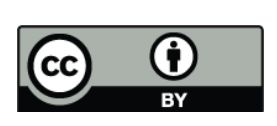

Correspondence to:

F. Domínguez-Castro

(f.dominguez.castro@gmail.com) cina and Morales Gila, 2001; Paredes et al, 2006; VicenteSerrano, 2006a, b; Vicente-Serrano and López-Moreno, 2006; Lana et al., 2008; Sousa et al., 2010). Most of these studies have been made from instrumental records (a length of approximately fifty years) and they focus mainly, in analysing the length of the drought periods or their spatial extension, since those variables are very closely related with the drought impact upon the society and the environment. Another important objective has been to divide the peninsula in homogeneous hydrologic regions, in order to be able to produce drought contingency plans for those regions. There seems to be a general agreement that most of Iberia has experienced a trend towards drier conditions in the recent decades, in a similar way as in many other Mediterranean regions, see Sousa et al. (2010) for details. Additionally, projections for future drought frequency indicate an even more noticeable increase, not only in drought frequency but also in intense precipitation frequency over the area (Zwiers and Kharin, 1998; Kharin and Zwiers, 2000; Tebaldi et al., 2006). However, due to the limited length of the available series, it is difficult to assess if the recorded trend is a signature of a low frequency variability pattern, or an anticipation of a future and drier climate in the region.

Consequently, in order to a more robust characterization of drought variability, it is indispensable to have series as long as possible. In Spain, precipitation series longer than one century are very rare and there are not many studies using those series (Vicente-Serrano, 2006a, b). In order to obtain longer precipitation time series, two have been the most important sources: tree rings (Creus-Novau et al., 1995, 1997; Saz and Creus-Novau, 1999; Saz, 2003) and documentary sources (Rodrigo et al., 1995, 1999; García et al., 2003a; Rodrigo and Barriendos, 2008). The later have been widely

Published by Copernicus Publications on behalf of the European Geosciences Union. 
used in the last years due to the development of some European research projects as IMPROVE (Camuffo and Jones, 20002), CLIWOC (http://www.ucm.es/info/cliwoc/), MILLENNIUM (http://millenniumproject.net) and initiatives at national levels (see Brázdil et al., 2005 and 2010 for a review). In other parts of the world the field is also very active, See Ge et al. (2005 and 2010), Aono and Kazui (2008), Hirano and Mikami (2008) for initiatives in Asia; or Prieto et al. (2000), García Herrera et al. (2003b and 2008), Prieto and García-Herrera (2009) for South America, for example.

However, it is difficult to find any paper centred in the analysis of droughts temporal and spatial variability in Spain for the pre-instrumental period. Rogations records for Zamora (Álvarez-Vázquez, 1986), Catalonia (MartínVide and Barriendos, 1995), Toledo, Seville and Catalonia (Barriendos, 1997), Alicante (Zamora, 2002), Zaragoza (Vicente-Serrano and Cuadrat, 2007) or Toledo (DomínguezCastro et al., 2008) are also available, but they focus only on local characteristics. Currently, new series and analysis are being produced for other Iberian locations like Badajoz, Huesca, Teruel and Barbastro within the Salvà-Sinobas project (http://salva-sinobas.uvigo.es/index/eng). In all the cited studies, frequency and intensity of droughts at a local level is analysed, however, none of them study drought patterns at a regional scale. In this paper, we present an analysis of regional drought patterns and their temporal variability built from some of those local rogation series for the preinstrumental $1600-1750$ period.

\section{Data and methods}

The present paper analyzes drought occurrence in Spain between 1600 and 1750 using rogations as a climate proxy. Rogations are religious rites celebrated in order to ask for a change in the meteorological situation during those periods when meteorological conditions caused impacts on the development of crops. Two types of rogations can be differenced according to pluviometric regime: "pro-pluvia" rogation, the rite celebrated when rain is needed; and "pro-serenitate" rogation, the one celebrated when rainfall is damaging crops.

The use of rogations as climate proxies started only recently, when Martín-Vide and Barriendos (1995) described precisely the climatic and social processes which originated the celebration of a rogation and the process in which it was recorded and kept in historical archives so that now we can access to all their information, from this contribution many authors have used this relationship between rogations and climate to reconstruct the pre-instrumental climate (mainly drought events) (Barriendos, 1997; Vicente Serrano and Cuadrat, 2007; Rodrigo and Barriendos, 2008; DomínguezCastro et al., 2008; Piervitali and Colacino, 2001)

The present paper is based in the use of "pro-pluvia" rogations, since they are those with information about the absence of rain and, thus, about droughts. It has to be kept in mind that rogations are not good proxies for every kind of drought. Wilhite and Glantz (1985) classified the droughts into four different types: meteorological, agricultural, hydrological and socioeconomic. Rogations are good proxies for agricultural droughts, since farmers were those who first noticed the lack of moisture for the development of the crops and it was them who contacted civil and ecclesiastic authorities and started the process leading to the celebration of a rogation. We have considered that a drought occurs when a "por pluvia" ceremony is recorded.

A drought is considered as agricultural when the moisture available in the soil is not enough to allow the normal development of crops, in any of their development stages. Thus, agricultural droughts do not depend only on meteorological conditions, but they are sensitive to other factors. The nature of the crops themselves or the different type of soil where they are planted can be very important elements for an agricultural drought to develop. As an example, in Spain, during the studied period, the cereal production was dominated by wheat followed by barley and rye, and only in some few Atlantic areas, corn was cultivated. The annual precipitation needed to grow these cereals is very similar for all of them (except corn) and it is quite variable, ranging from 400 to $800 \mathrm{~mm}$. Anyhow, it has to be stressed that the total annual precipitation is not a good index to evaluate the hydrological requirements of these cereals, since the distribution of the precipitation along the plant cycle is much more important, particularly in the Mediterranean area, where the precipitation is concentrated in few months. The length of the moisture-sensitive period has been shown to vary with different cereal crops (Skazkin, 1961). Barley presents a shorter cycle than the other cereals and, consequently, it resists better the drought and can grow with less than $300 \mathrm{~mm}$ per year. On the other hand, corn has a long growth phase and needs, at least, $150 \mathrm{~mm}$ during the summer months (Martin et al., 2006). The wheat and the rye have similar grow cycles and the main difference between both is that rye can grow with lower temperatures than wheat.

In this paper, the seven most complete rogations series in the Iberian Peninsula, for the period 1600-1750 (Seville, Murcia, Toledo, Zamora, Zaragoza, Catalonia and Bilbao) (Fig. 1), have been used in order to characterize the spatial and temporal variability of intense droughts in Spain. All these series have been built from primary documentary sources like Capitular Acts or Municipal Minutes (MartínVide and Barriendos, 1995; Barriendos, 1997; VicenteSerrano and Cuadrat, 2007; Domínguez-Castro et al., 2008; Rodrigo and Barriendos, 2008). Most of them are built from rogations from a single archive, but the Catalonian series, which was built with data from different sites like Girona, Barcelona, Tarragona and Tortosa, so this series being representative of the northern Mediterranean area of Spain (Fig. 1). 


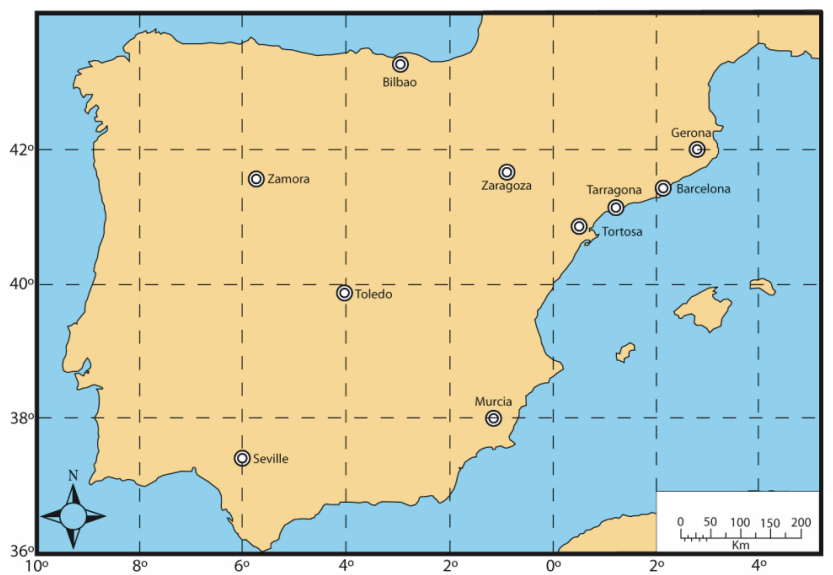

Fig. 1. Location of the rogation series used in this manuscript.

The documentary homogeneity of the rogation series is guaranteed by the quality and reliability of the documents consulted. These rogations are extracted from collections of public institutions, and their contents are certified by a public notary. The documentation consulted is continuous over the whole studied period.

Several arguments have been used in previous papers to confirm the homogeneity of rogations as a proxy of droughts (Martin-Vide and Barriendos, 1995; Barriendos, 1997) being the most important:

- The rigidity of the institutions of the ancient regime prevented any disorder in any subject, especially in liturgical matters. Any substantial change was clearly reflected in the documents (i.e. there are no discontinuities in the collection and no changes in the rogation procedures nor the recording processes).

- The agriculture in Spain did not experience significant advances neither in the applied techniques nor in the introduction of new tools or practices that increased significantly the production during the studied period. Therefore Spain continued suffering subsistence crises in large areas until the early twentieth century. The propluvia rogations were for centuries the unique "remedy" to droughts for the agriculture on dry lands.

Figure 2 shows the length of the different series. It can be seen that some series start at the late 15th century (Gerona and Tarragona) or early 16th century (Zamora and Toledo), but many of them (Bilbao, Zaragoza, Zamora and Murcia) begin to have an acceptable confidence level only from the late 16th or the early 17 th century, due mainly to the scarcity of administrative documentary sources in this early stage. The last years of most of the series, mostly in the 19th century, are clearly characterized by a dramatic fall in the number of rogations, mostly associated to two non climatic factors: a technical one, with better farming and irrigation meth-

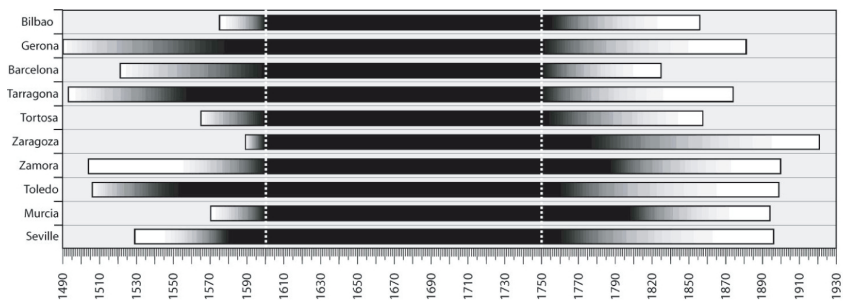

Fig. 2. Length of rogation series. Darker areas denote a higher confidence in rogation series quality.

ods, partly reducing the farming dependence upon meteorological conditions. Secondly, a social factor generated after Napoleonic Wars with strong opposition to absolutism in urban areas focused on anticlericalism (Jiménez de Gregorio, 1984; Lorente-Toledo, 1993). During the central decades of 19th century the rogations records decay: because initially they were excluded of administrative documents of City Councils and; then, civil authorities refused to. Previous works in these locations (Martín-Vide and Barriendos, 1995, 1997; Vicente Serrano and Cuadrat, 2007; Rodrigo and Barriendos, 2008; Domínguez-Castro et al., 2008) suggest that the period 1600-1750 was the longest with homogeneous data for all the series.

Rogation series include information on a daily basis. The exact date of each rogation is known and, additionally, we know that the bureaucratic process leading to its celebration, which began when farmers decided that, a rogation was needed and ended when the rite was celebrated, lasted about three days. However, it is not possible to identify spatial patterns at a daily scale from rogation series, because a perfect coincidence in the day of the celebration of rogations in two different cities is very unusual, even if rogations at those locations were indicating that both were under the same drought episode. On the other hand, the analysis of rogation series at an annual scale can lead to conclusions very difficult to interpret, since agricultural water needs are characterized by a very marked seasonal cycle. Precisely, this seasonal cycle has as a consequence a higher number of rogations during the most critical seasons for crop development, spring and autumn in Spain. Consequently, we decided to perform a seasonal analysis of rogation series. We have considered that a drought has affected one of the analysed sites when at least one rogation has been celebrated during the season.

To verify if seven locations (Seville, Murcia, Toledo, Zamora, Zaragoza, Catalonia and Bilbao) are enough to characterize the extension drought in the Iberian Peninsula a detailed analysis from secondary documentary sources (Rico Sinobas, 1850; Villar and Macias, 1887; Estrada Segalerva, 1970; Fontana Tarrats, 1971-1977; 1974-1975; 1976; Álvarez Saenz de Buruaga, 1994; Ramírez de las Casas Deza, 1995) has been made for two of the most extended droughts identified with rogation series: 
Table 1. Sites with a drought documentarily registered in spring 1664, location, date and detail about the information extracted.

\begin{tabular}{|c|c|c|c|}
\hline No. & Locality & Celebration/Cause & Date \\
\hline 1 & Bilbao & $\begin{array}{l}\text { General procession/high necessity of water } \\
\text { for production (fruits of the earth) }\end{array}$ & 7th May \\
\hline 2 & Merindad de Ubierna & $\begin{array}{l}\text { General procession/scarcity of water for } \\
\text { the pasture }\end{array}$ & 26th May \\
\hline 3 & Burgos & General procession/by the drought & 8th May \\
\hline 4 & Soria & Simple rogations/by the drought & Spring \\
\hline 5 & Zamora & $\begin{array}{l}\text { Exhibition of images/Water needs for } \\
\text { breads and fruits }\end{array}$ & 19th Apr \\
\hline 6 & Zaragoza & $\begin{array}{l}\text { Masses and processions with the intercessor } \\
\text { within the church/by the drought }\end{array}$ & Apr \\
\hline 7 & Barcelona & Simple rogations/by the drought & 15th-27th May \\
\hline 8 & Salamanca & General procession/by the drought & 20th Apr-23 May \\
\hline 9 & Toledo & $\begin{array}{l}\text { General Procession/by the great } \\
\text { scarcity of water }\end{array}$ & 1st Feb-15th May \\
\hline 10 & Badajoz & $\begin{array}{l}\text { General Procession/by the great } \\
\text { infertility due to the drought }\end{array}$ & May \\
\hline 11 & Úbeda & General Procession/extreme drought & 2nd May \\
\hline 12 & Córdoba & General Procession/extreme drought & First days of Apr \\
\hline 13 & Jaén & General procession/by drought & Spring \\
\hline 14 & Murcia & $\begin{array}{l}\text { Exhibition of images/by the great } \\
\text { needs of water on the fields }\end{array}$ & 24th Mar-9th May \\
\hline 15 & Sevilla & $\begin{array}{l}\text { General procession/by the scarcity } \\
\text { of water }\end{array}$ & 28th Apr \\
\hline 16 & Loja & Petition in church/by drought & 2nd Sep \\
\hline 17 & Malaga & $\begin{array}{l}\text { General procession/to remedy the drought } \\
\text { was agreed to bring water through pipes } \\
\text { from the river Guadelmedina to supply fountains }\end{array}$ & 5th May \\
\hline
\end{tabular}
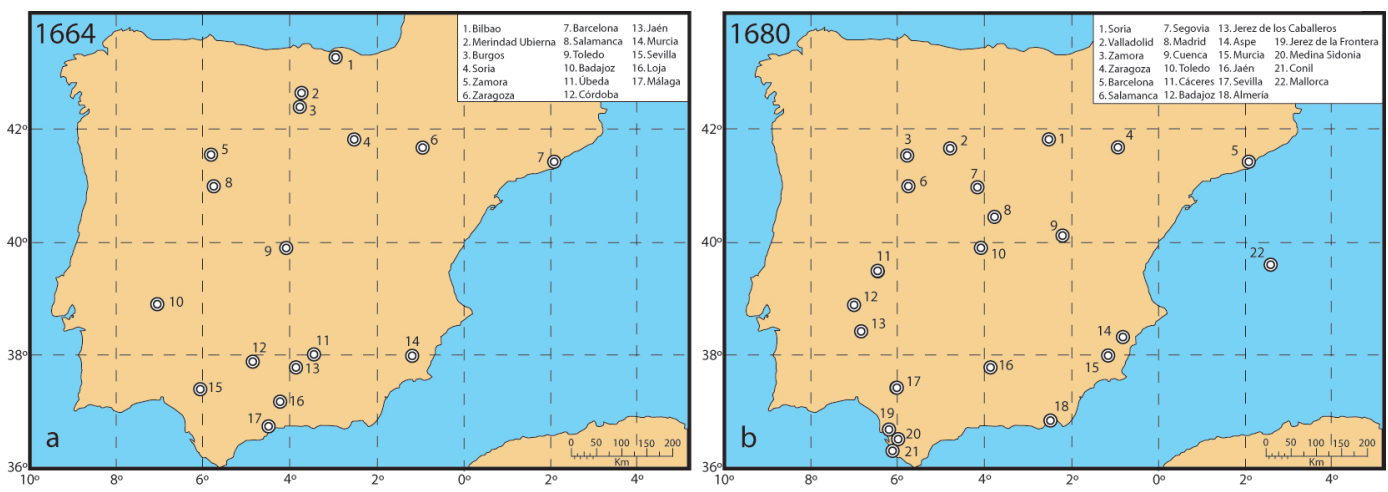

Fig. 3. Sites with a drought documentarily registered in spring 1664 (a) and spring 1680 (b).

- Spring 1664: the only drought affecting to all the seven sites with rogation series (Fig. 3a and Table 1).

- Spring 1680: drought affecting to all sites but Bilbao. It is the longest lasting drought between 1506 and 1900 in Toledo (Dominguez-Castro et al., 2008) (Fig. 3b and Table 2).
Figure 3 and Tables 1 and 2 include many of the locations where secondary documentary sources with information about these droughts and their effects have been found. The figure shows that both drought episodes are homogeneously distributed throughout most of the Iberian Peninsula, with no gaps in the documentary references about the drought or its impacts. The exception in the north of the Peninsula, in the 1680 drought, was expected known that Bilbao had no rogation registered for that year and season. 
Table 2. Sites with a drought documentarily registered in spring 1680, location, date and detail about the information extracted.

\begin{tabular}{|c|c|c|c|}
\hline No. & Locality & Celebration/Cause & Date \\
\hline 1 & Soria & $\begin{array}{l}\text { General procession/by the drought and thanksgiving } \\
\text { masses for the rain obtained }\end{array}$ & 30th Apr \\
\hline 2 & Valladolid & Exposure of the intercessor in church/great drought & 4th Apr \\
\hline 3 & Zamora & General procession/by the water shortage & 11th Feb-28 Apr \\
\hline 4 & Zaragoza & $\begin{array}{l}\text { Masses and processions with the intercessor } \\
\text { within the church/by the drought }\end{array}$ & Mar-Aug \\
\hline 5 & Barcelona & $\begin{array}{l}\text { General procession } / 4 \text { months without rain, the winds } \\
\text { dry up the crops }\end{array}$ & 16th Feb-17 May \\
\hline 6 & Salamanca & Exposure of the intercessor in church/by the drought & 31st Mar \\
\hline 7 & Segovia & $\begin{array}{l}\text { Exposure of the intercessor in church/by the drought, } \\
\text { in may thanksgiving masses }\end{array}$ & 26th Mar \\
\hline 8 & Madrid & General procession/drought in Castilla la Nueva & Apr \\
\hline 9 & Cuenca & $\begin{array}{l}\text { General procession ( } 20.000 \text { people)/even the snow wells } \\
\text { are dried. The last rain was 26th December } 1679\end{array}$ & 4th Apr \\
\hline 10 & Toledo & $\begin{array}{l}\text { General procession/by the drought, thanksgiving masses } \\
\text { 14th May }\end{array}$ & 17th Mar \\
\hline 11 & Badajoz & General procession/by the drought & 21st Mar \\
\hline 12 & Cáceres & $\begin{array}{l}\text { General procession/no rainfall in the first three months, } \\
\text { and the last autumn was drier }\end{array}$ & 8th Mar-21 Apr \\
\hline 13 & Jerez de los caballeros & General procession/by the drought & April \\
\hline 14 & Aspe & General procession/by the drought & 10th-31st Mar \\
\hline 15 & Murcia & General procession/by the lack of water for the crops & 13th Feb-4th Apr \\
\hline 16 & Jaén & General procession/by the drought & Spring \\
\hline 17 & Sevilla & $\begin{array}{l}\text { General procession/by the gravity of the drought for } \\
\text { the land and fruits }\end{array}$ & 8th-23rd Mar \\
\hline 18 & Almería & Extraordinary rogation/by the drought & 29th Mar \\
\hline 19 & Jerez de la Frontera & General procession/by the drought & Apr \\
\hline 20 & Medina sidonia & Petition in church/lack of rain & Spring \\
\hline 21 & Conil & Petition in church/lack of rain & Spring \\
\hline 22 & Mallorca & $\begin{array}{l}\text { Petition in church/the wells and the Palma channel were } \\
\text { dry, barely rain until halfway through October }\end{array}$ & 11th Feb \\
\hline
\end{tabular}

Additionally, secondary documentary sources provide information about the intensity of the drought. Both analysed cases, 1664 and 1680, were severe droughts, being the second one more severe. In 1664, the drought did not only affect the crops, but also de cattle. Villar and Macias (1887) wrote about its impact in Salamanca: "the drought sterilized the fields and caused big mortality among the cattle"; also in Burgos, where farmers were concerned about cattle: "there is not enough water for the pasture" (Fontana Tarrats, 1971-1977). References about the drought in 1680 describe it as very long. In the Balearic Islands, it almost did not rain between February and October (Fontana Tarrats, 19741975): "Rogations begin on February 11th with very limited success. Crops are scarce. Wells dry up and La Palma irrigation ditch was narrowed with almost no water. It barely rained until mid October". In Cuenca, an extreme drought is described by Fontana Tarrats (1971-1977): “An extreme drought in Cuenca, water is scarce even in the snow wells". And in Castilla la Nueva (southern half of the central Iberian
Plateau), the drought began in the previous winter (RicoSinobas, 1850): "It was noticeable the dryness in Castilla la Nueva during winter and spring...".

Another difference between the two droughts is the date, the Table 1 show that most of the rogation ceremonies in 1664 were in April and May nevertheless in 1680 were in March and April (Table 2).

Thus, secondary sources for both droughts agree with the results obtained from rogation series.

\subsection{Seasonality of rogation series}

As previously described, rogation series are characterized by a high seasonality caused by the march in farming water demands. But this demand is very variable throughout the Iberian Peninsula since it depends on local climate and local farming needs. Consequently, rogation series at different sites are characterized by noticeable differences in their seasonal evolution. For example, Bilbao, in the northern 


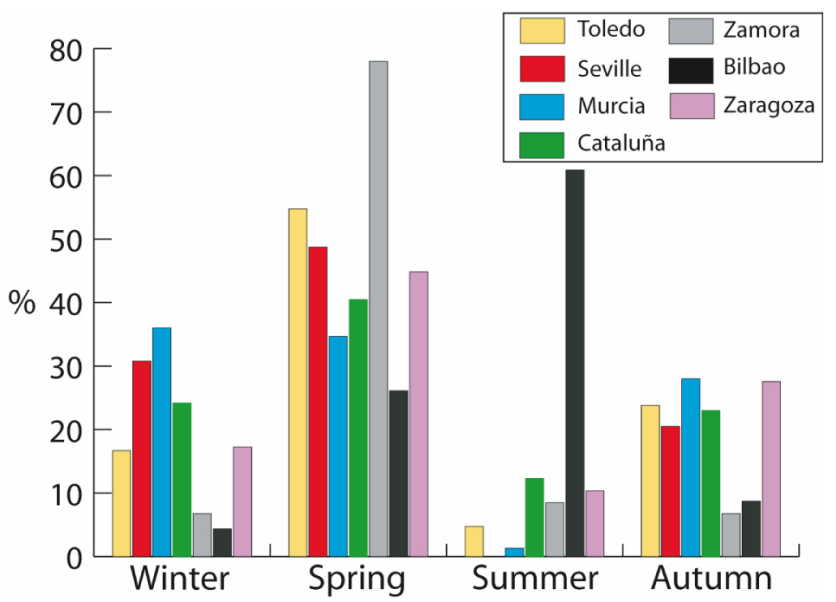

Fig. 4. Rogation series seasonality at the seven analysed sites.

Atlantic edge of the Peninsula, shows a seasonal evolution very different from the rest, with the highest percentage of rogations being celebrated during summer, while spring is the season the highest rogation occurrence in all other sites, particularly in Zamora, Toledo and Seville (see Fig. 4). In Zaragoza, Catalonia and Murcia, differences among spring, autumn and winter are much reduced. In Seville, Catalonia and Murcia, i.e., all the coastal areas but Bilbao, winter is the second season with most rogations, while it is autumn in interior areas like Toledo and Zaragoza.

But seasonality is not the only difference among different regions. The number of rogations is very variable as well. Table 3 shows that the Mediterranean regions (Catalonia and Murcia) have many more rogations in the studied period than any other region, although the number of rogation ceremonies in Catalonia could be overrated because it is built as a synthesized series from four different locations. The reason is that crops in these areas are much closer to their ecological limit and, thus, they suffer more easily from a lack of water availability for the development of their crops.

When using rogations as drought proxies, it has to be kept in mind that the intensity of the associated drought depends on the considered season (Domínguez-Castro et al., 2008). For example, in a semiarid region where dry-land crops are grown, a small delay in the beginning of spring rains can lead to the celebration of rogation due to the potential loss of the crops, while in summer, no rogation would be made unless the scarcity of water is so big that there is not enough for cattle or even for human use. Similar arguments are valid for the different sites studied in this paper. The percentage of water deficit which will cause damage in crops grown in wet lands (like Bilbao) is much higher than in semiarid areas (Murcia) and, thus, rogations will be much more frequent in drier areas.

In summary, it can be said that the analysis of drought intensity from rogation series will be different depending on the analysed area and on the season of their celebration.
Table 3. Number of years with rogations for every season and for the whole year.

\begin{tabular}{lccccc}
\hline Location & Winter & Spring & Summer & Autumn & Sum \\
\hline Toledo & 14 & 46 & 4 & 20 & 84 \\
Zamora & 4 & 46 & 5 & 4 & 59 \\
Zaragoza & 15 & 39 & 9 & 24 & 87 \\
Seville & 12 & 19 & 0 & 8 & 39 \\
Catalonia & 61 & 102 & 31 & 58 & 252 \\
Murcia & 81 & 78 & 3 & 63 & 225 \\
Bilbao & 1 & 6 & 14 & 2 & 23 \\
\hline
\end{tabular}

Table 4. Conditional probability of rogation celebration when a rogation has been celebrated in Toledo.

\begin{tabular}{lcccc}
\hline & Winter & Spring & Summer & Autumn \\
\hline Seville & 0.33 & 0.79 & $*$ & 0.38 \\
Catalonia & 0.16 & 0.39 & 0.03 & 0.17 \\
Murcia & 0.11 & 0.27 & 0.00 & 0.14 \\
Zamora & 0.50 & 0.52 & 0.00 & 0.75 \\
Zaragoza & 0.27 & 0.41 & 0.11 & 0.25 \\
\hline
\end{tabular}

* No rogations on this site and season.

Thus, in this work we have worked at a seasonal scale and we do not attempt to evaluate the intensity of the identified droughts but only their spatial extension.

\section{Results}

The spatial extension of drought episodes during the period $1600-1750$ has been analysed using Toledo as the reference. In addition to the fact that Toledo is nearly in the centre of the analysed sites, there are other reasons for this. First, it includes 84 rogations, which is an intermediate number between more than 200 rogations in the Mediterranean sites (Catalonia and Murcia) and less than 40 rogations in those sites with the lowest number (Bilbao and Seville). Second, Toledo is characterized by the highest values when conditional probability of simultaneous drought occurrence between any two sites is computed. Table 4 shows the conditional probability of a rogation celebration when a rogation is celebrated in Toledo.

As expected, the highest conditional probability values with Toledo are obtained for Zamora. This is because they are the two cities with the most similar climate (continental with Atlantic influence). The following one is Seville, again a city with an important influence from the Atlantic. In fact, in spring, values for Seville are higher than for Zamora. Conditional probability values for Zaragoza, with a continental climate but under Mediterranean influence, are lower. Much 

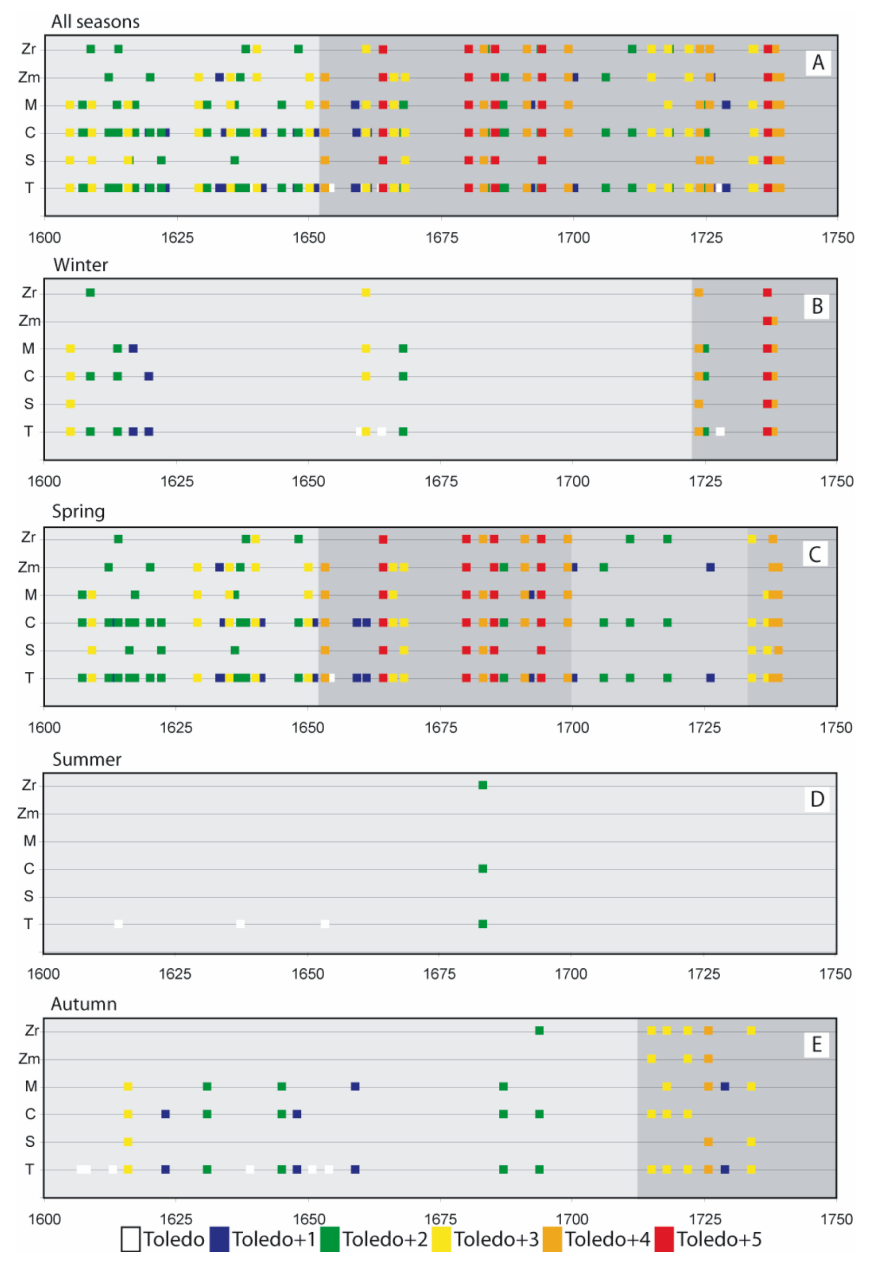

Fig. 5. Annual and seasonal simultaneous rogations in Toledo (T) and any other site, Seville (S), Catalonia (C), Murcia (M), Zamora $(\mathrm{Zm})$, Zaragoza $(\mathrm{Zr})$, for the period 1600-1750.

lower values are obtained for Catalonia and Murcia, with a climate very different to that in Toledo. Finally, Toledo series is the best scrutinised rogation series in the Iberian Peninsula. From Barriendos et al. (1997) and Dominguez-Castro et al. (2008) we know about its main features and the length of the droughts affecting Toledo at a daily scale. Thus, our knowledge about this series is an important background for the interpretation of the new results.

Figure 5 includes all the droughts recorded in Toledo, and shows which of them coincide with droughts in other regions. White boxes represent seasons when Toledo is the only area where a rogation is celebrated. Blue boxes indicate that rogations were celebrated in Toledo and another region (Toledo +1 ), green for Toledo +2 , yellow for Toledo +3 , orange for Toledo +4 and red for Toledo +5 . Figure 5 does not include the Bilbao series, since only one case is coincident for this series and Toledo. That case is spring 1664, when rogations were celebrated in all the available locations. This lack of coincidence between Bilbao and Toledo is due, as explained before, to the noticeable differences between their climates and crops, as easily observable in the seasonality of rogations previously shown (Fig. 4).

The analysis of Fig. 5a shows that, at the annual scale, two different periods are easily identified:

- Period 1 (first half of 17th century): Droughts are characterized by a limited spatial extension. Four (Toledo + 3 ) is the highest number of regions with simultaneous droughts.

- Period 2 (second half of 17th and first half of 18th centuries): Rogations are celebrated simultaneously in a higher number of locations. Along this period, all the cases of rogations simultaneously celebrated in five or more locations (Toledo +4 and Toledo +5 ) are recorded. Spring 1664, the only year with seven simultaneous rogations, is included in this period.

The seasonal analysis (Fig. 5b, c, d and e) shows that this division into two sub-periods is due, mostly, to spring droughts (Fig. 5c), since spring is the season with the highest number of rogations. However, spring series has a period, from early 18 th century to $1730 \mathrm{~s}$, when droughts are very scarce and their extension is very limited, affecting only to two (Toledo +1 ) or three (Toledo +2 ) locations, thus, with characteristics very similar to those of period 1 (fist half of 17 th century) described in the annual analysis. In winter (Fig. 5b), the increase of droughts extension occurs in 1724, while it is in 1715 for autumn series (Fig. 5e). In summer, the scarce number of rogations celebrated makes it impossible to identify any separation between both periods.

In order to verify whether this change in the spatial extension of the drought pattern depends on the location used for the analysis, we computed the frequency of simultaneous occurrence in any of the considered locations, not only with Toledo as in Fig. 5. Figure 6 shows the results for both periods. Here 0 means that no droughts are recorded, 1 that it is recorded in just one location (Toledo or any other) and so on until it is detected in the seven analyzed locations. We have done so both for period 1 and period 2 and for the different seasons (Fig. 6). As seen in Fig. 5, the transit between both sub periods is not simultaneous for every season, being approximately in 1724 for winter, 1653 for spring and 1715 for autumn. Consequently, both periods have a different length in Fig. 6. The most noticeable differences occur in spring, when changes in drought extensions are more evident. Years with no drought (0 locations) or with local droughts ( 1 or 2 locations) show up during both periods with a very similar frequency. However, looking in the tail of the figure it can be seen that widely extended droughts $(5,6$ or 7 locations affected) do not appear during period 1 (first half of 17th century) and are only identified during period 2 .

These differences are not so well marked in the other seasons. Winter and autumn show drought frequencies very similar along both periods for 3 locations (autumn) and 4 

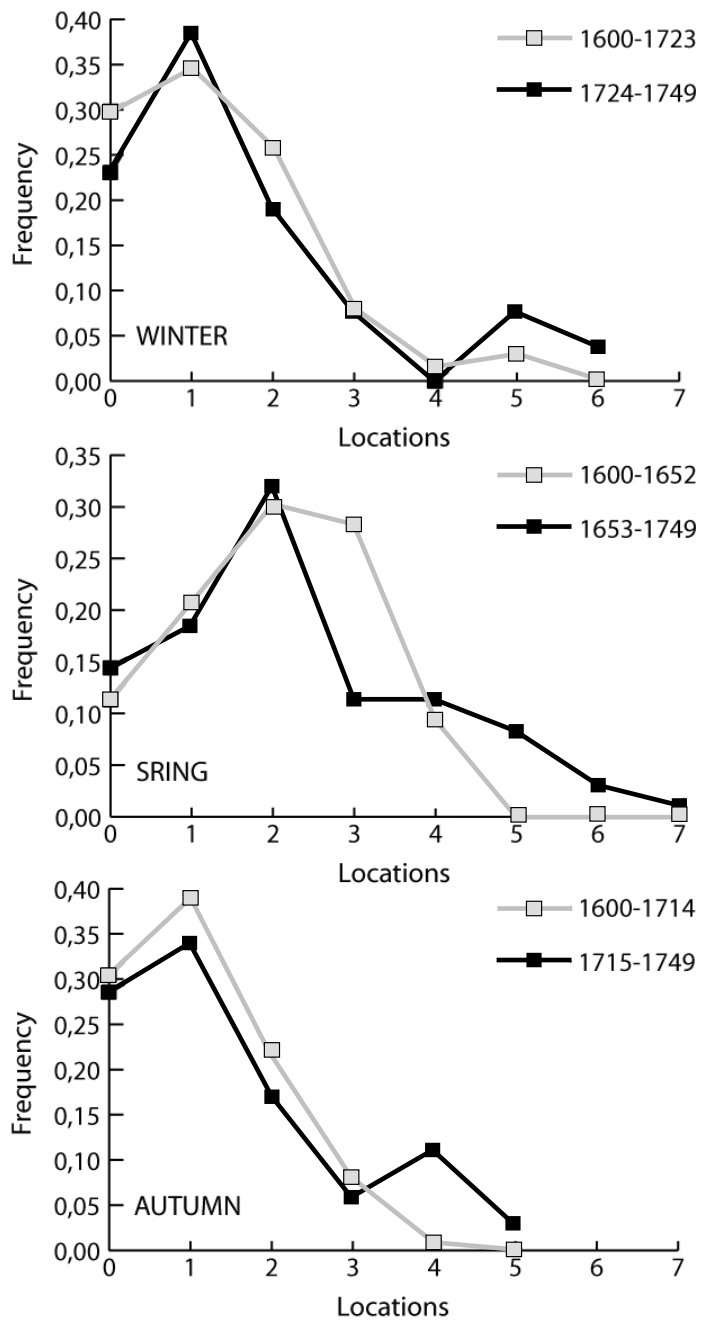

Fig. 6. Frequency of different drought extensions from 0 (no drought detected during the season) to 7 (drought detected in all the studied locations) during periods 1 and 2 in winter, spring and autumn.

locations (winter). Period 2 shows a slight increase in the frequency of droughts affecting 5 or 6 locations during winter, and for droughts affecting 4 or 5 locations during autumn.

These results confirm that the shift in the drought pattern during the mid 17 th century is not a characteristic of the Toledo series but it is a general feature for the whole Iberian Peninsula. It is seen, as well, that this shift is more evident during spring than in any other season, even when this fact could be due to the bias induced by the proxy used. This was expected since spring is the season with the highest number of rogations and when the development of traditional Iberian crops is more critical.

Precipitation in the Iberian Peninsula, and droughts, show a high spatial variability caused by its orographic complexity and to the high number of atmospheric mechanism processes affecting precipitation. These physical mechanisms and its consequences have been studied and related with the main patterns of atmospheric circulation in the Atlantic sector and at hemispheric and global scales (von Storch et al., 1993; Martín-Vide and Fernandez, 2001; Pozo-Vázquez et al., 2001, 2004). Precipitation over the Peninsula has been studied, as well, associated with different weather types (Goodes and Palutikof, 1998; Trigo and DaCamara, 2000; Goodes and Jones, 2002; Paredes et al., 2006; VicenteSerrano and López Moreno, 2006).

In order to analyse droughts affecting to those regions with differenced precipitation patterns, we have classified three different types: Mediterranean (affecting, at least, Catalonia, Murcia and Zaragoza); Atlantic (affecting, at least, Seville, Toledo and Zamora) and Iberian (affecting to the six locations). This division was made based in the studies cited in the previous paragraph and confirmed by the conditional probability analysis performed with rogation series (Table 4, for Toledo). In fact, this distribution resembles much to that presented in Vicente-Serrano (2006b), when they analyze Iberian agricultural droughts from instrumental data, even when we use only 7 sites and, consequently, contours are not so well defined as in their classification, made from 51 observation points.

Time evolution of the three drought types is presented in Fig. 7 (boxes). This figure shows very clearly the separation between period 1 (first half of 17 th century), when no regional droughts are identified; and period 2 (second half of 17 th and first of 18th), with abundance of regional droughts. Again, from this figure, it becomes evident that the shift in drought pattern in 1653 affects to the whole Peninsula and not only to parts of it.

Figure 7 also shows that period 2 has a differenced subperiod from early 18 th to 1730 s (discontinuous line), when only Mediterranean droughts are identified. In fact, this subperiod coincidences with the period when the spatial extension of the spring droughts was very limited, similar to period 1 in the main division (Fig. 5c). However, Fig. 7 shows that this sub-period is very different to period 1 , since in period 1 no droughts are identified at all, while, along this new subperiod, Mediterranean drought frequency is very similar to the rest of period 2, but with no Atlantic droughts.

\section{Conclusions}

Rogation series suggest a shift in the drought distribution pattern in the Iberian Peninsula during 1650s, with two clearly differenced periods: period 1 (first half of 17 th century), when local droughts, affecting only a few sites in the Peninsula, are dominant; and period 2 (second half of 17 th and first of 18th), when droughts affect to more sites simultaneously and regional or peninsular scale droughts can be identified.

Finally, it is noticeable that the spatial shift in the Iberian droughts pattern during the mid-seventeenth century matches quite well with the onset of the Maunder Minimum 


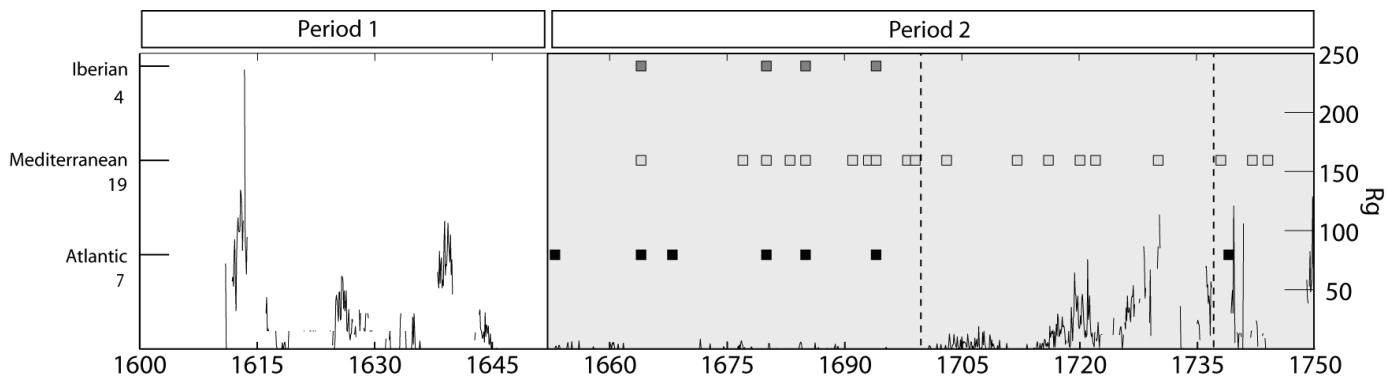

Fig. 7. Boxes identify spring droughts: Iberian (dark gray), Mediterranean (light gray) and Atlantic (black). The lower line indicates the yearly sun-spot number (right axis; data from "Group Sunspot Number").

(1645-1715) (See Fig. 7). All the Iberian droughts and all the Atlantic droughts, but the one in 1739, are identified during this minimum in solar activity. Even if speculative, this coincidence could be indicating that solar activity could be a relevant forcing for this shift. However, this asseveration should be considered with caution, since there are no previous studies detecting this relationship during the instrumental period and we lack of a physical mechanism to explain it.

Acknowledgements. This work has been supported by the "SalvàSinobas project: Climatic Variability Characterization in the Iberian Peninsula during the Period 1750-1850" financed by the Ministry of the Environment, Rural and Maritime Affairs of Spain (ref. 200800050083542)

We want to thank Sergio Vicente Serrano and José María Cuadrats for providing the Zaragoza rogation data used in this work. Also the authors appreciate the helpful and constructive comments of both reviewers (Fredrik Charpentier Ljungqvist and Philip Brohan).

Edited by: J. Guiot

\section{References}

Álvarez Saenz de Buruaga, J.: Materiales para la historia de Mérida (de 1637 a 1936), Ayuntamiento de Badajoz, Badajoz, Spain, 1994.

Álvarez Vázquez, J. A.: Drought and Rainy Periods in the Province of Zamora in the 17th, 18th, and 19th Centuries, in: Quaternary Climate in Western Mediterranean, Universidad Autónoma de Madrid, Madrid, Spain 221-233, 1986.

Aono, Y. and Kazui, K.: Phenological data series of cherry tree flowering in Kyoto, Japan, and its application to reconstruction of springtime temperatures since the 9th century, Int. J. Climatol., 28, 905-914, 2008.

Barriendos, M.: Climatic variations in the Iberian peninsula during the late Maunder minimum (AD 1675-1715): an analysis of data from rogation ceremonies, The Holocene, 7, 105-111, 1997.

Brázdil, R., Pfister, C., Wanner, H., von Storch, H., Luterbacher, J.: Historical climatology in Europe - the state of the art, Climatic Change, 70, 363-430, 2005.

Brázdil, R., Dobrovolný, P., Luterbacher, J., Moberg, A., Pfister, C., Wheeler, D., and Zorita, E.: European climate of the past
500 years: new challenges for historical climatology, Climatic Change, 101(1-2), 7-40, 2010.

Camuffo, D. and Jones, P.: Improved Understanding of Past Climatic Variability from Early Daily European Instrumental Sources. Kluwer Academic Publishers, Dordrecht, Boston, London, 2002.

Creus-Novau, J., Zozaya, B., and Fernandez Cancio, A.: Reconstrucciones climáticas en Galicia durante las últimas centurias: estudio dendrocronologico, Xunta de Galicia, Santiago de Compostela, Spain, 1995.

Creus-Novau, J., Fernández, A., and Manrique, E.: Dendrocronología y clima del último milenio en España. Aspectos metodológicos y avance de resultados, in: El paisaje mediterráneo a través del espacio y del tiempo. Implicaciones en la desertificación, Geoforma, Logroño, Spain, 1997.

Domínguez-Castro, F., Santisteban, J. I., Barriendos, M., and Mediavilla, R.: Reconstruction of drought episodes for central Spain from rogation ceremonies recorded at Toledo Cathedral from 1506 to 1900: A methodological approach, Global Planet. Change, 63, 230-242, 2008.

Estrada Segalerva, J. L.: Efemérides malagueñas, Imprenta San Andrés, Malaga, Spain 1970.

Estrela, M. J., Peñarrocha, D., and Millán, M.: Multi-annual drought episodes in the mediterranean (Valencia region) from 1950-1996. A spatio-temporal análisis, Int. J. Climatol., 20, 1599-1618, 2000.

Fontana Tarrats, J. M.: Entre El cardo y la rosa. Historia del clima en las mesetas, Madrid, 269 pp., Unedited typewritten work, 19711977.

Fontana Tarrats, J. M.: El clima de Baleares, hoy y ayer: 14501700, Madrid, 104 pp., Unedited typewritten work, 1974-1975.

Fontana Tarrats, J. M.: Quince siglos de clima andaluz, Madrid, 166 pp., Unedited typewritten work, 1976.

García, R., Macías, A., Gallego, D., Hernández, E., Gimeno, L., and Ribera, P.: Reconstruction of the precipitation in the Canary Islands for the period 1595-1836, B. Am. Meteorol. Soc., 84, 1037-1039, 2003a.

García Herrera, R., García, R. R., Prieto M. R., Hernández, E., Gimeno, L., and Díaz, H. F.: The use of Spanish historical archives to reconstruct climate variability, Bull. Am. Meteorol. Soc., 84, 1025-1035, 2003b.

García Herrera, R., Barriopedro, D., Hernández, E., Diaz, H. F., Garcia, R. R., Prieto, M. R., and Moyano, R.: A chronology of El Niño events from primary documentary sources in Northern 
Peru, J. Climate, 21, 1948-1962, 2008.

Ge, Q., Zheng, J. Y., Hao, Z. X., Zhang, P. Y., and Wang, W. C.: Reconstruction of historical climate in China. High-resolution precipitation data from Qing Dynasty archives, Bull. Am. Meteorol. Soc., 86, 671-679, 2005.

Ge, Q., Zheng, J. Y., Hao, Z. X., Shao, X. M., Wang, W. C., and Luterbacher, J.: Temperature variation through 2000 years in China: an uncertainty analysis of reconstruction and regional differences, Geophys. Res. Lett., 37, L03703, doi:10.1029/2009GL041281, 2010.

Gil Olcina, A. and Morales, Gil, A.: Causas y Consecuencias de la Sequía en España, Instituto Universitario de Geografía de la Universidad de Alicante y Caja de Ahorros del Mediterraneo, Alicante, Spain, 2001.

Goodess, C. M. and Palutikof, J. P.: Development of daily rainfall scenarios for southeast Spain using a circulation-type approach to downscaling, Int. J. Climatol., 18, 1051-1083, 1998.

Goodess, C. M. and Jones, P. D.: Links between circulation and changes in the characteristics of Iberian rainfall, Int. J. Climatol., 22, 1593-1615, 2002.

Hirano, J. and Mikami, T.: Reconstruction of winter climate variations during the 19th century in Japan, Int. J. Climatol., 28, 14231434, 2008.

Jiménez de Gregorio, F.: El ayuntamiento de Toledo en la guerra por la independencia y su entorno, de 1809 a 1814, Instituto Provincial de Investigaciones y Estudios Toledanos, Toledo (in Spanish), 1983.

Kharin, V. V. and Zwiers, F. W.: Changes in the extremes in an ensemble of transient climate simulation with a coupled atmosphere-ocean GCM, J. Climate, 13, 3760-3788, 2000.

Lana, X., Martínez, M. D., Burgueño, A., Serra, C., Martín-Vide, J., and Gómez, L.: Spatial and temporal patterns of dry spell lengths in the Iberian Peninsula for the second half of the twentieth century, Theor. Appl. Climatol., 91, 99-116, 2008.

Lorente-Toledo, L.: Agitación urbana y crisis económica durante la guerra de la independencia y su entorno de 1809 a 1814, Publicaciones de la Universidad de Castilla-La Mancha (in Spanish), 1993.

Martin, J. H, Warren L. H., Stamp D. L., and Waldren, R. P.: Principles of field crop production. Prentice Hall, Upper Saddle River, N.J, 2006.

Martín-Vide, J. and Barriendos, M.: The use of rogation ceremony records in climatic reconstruction: a case study from Catalonia (Spain), Climatic Change, 30, 201-221, 1995.

Martín-Vide, J. and Fernández, D.: El índice NAO y la precipitación mensual en la España peninsular, Investigaciones Geográficas, 26, 41-58, 2001.

Martín-Vide, J. and Gomez, L.: Regionalization of peninsular Spain based on the length of dry spells, Int. J. Climatol., 19, 537-555, 1999.

Olcina, J.: Tipología de las sequías en España, Ería, 56, 201-227, 2001.

Paredes, D., Trigo, R. M., García-Herrera, R., and Trigo, I. F.: Understanding precipitation changes in Iberia in early spring: weather typing and storm-tracking approaches, J. Hydrometeorol., 7, 101-113, 2006.

Pérez-Cueva, A. and Escriva-Ortega, J.: Análisis de la sequía en el ámbito mediterraneo, Cuadernos de Geografía, 30, 1-12, 1982.

Piervitali, E. and Colacino, M.: Evidence of drought in western
Sicily during the period 1565-1915 from liturgical offices, Climatic Change 49, 225-238, 2001.

Pozo-Vázquez, D., Esteban-Parra, M. J., Rodrigo, F. S., and CastroDíez, Y.: A study on NAO variability and its possible non-linear influences on European surface temperatures, Clim. Dyn., 17, 701-715, 2001.

Pozo-Vázquez, D., Tovar-Pescador, J., Gámiz-Fortis, S. R., Esteban-Parra, M. J., and Castro-Díez, Y.: NAO and solar radiation variability in the European North Atlantic region, Geophys. Res. Lett., 31, 5, doi:10.1029/2003GL018502, 2004.

Prieto, M. R., García Herrera, R., and Dussel, P.: Archival evidence for some aspects of historical climate variability in Argentina and Bolivia during the 17th and 18th centuries. In: Southern Hemisphere Paleo- and Neoclimates, Key sites, methods, data and models. Springer, Berlin, 2000.

Prieto, M. R. and García-Herrera, R.: Documentary sources from South America: Potencial for climate reconstruction, Palaeogeogr. Palaeocl., 281(3-4), 196-209, 2009.

Ramírez de las Casas Deza, L. M.: Anales de la ciudad de Córdoba: desde el siglo XIII y año de 1236 en que fue conquistada por el rey Santo Rey Don Fernando III hasta el de 1850, Ayuntamiento Córdoba, Córdoba, Spain, 1995.

Rico Sinobas, M.: Fenómenos meteorológicos en la Península Ibérica desde el siglo IV hasta el XIX, Archive of Royal Academy of Medicine of Madrid, Manuscripts, 23-4ํ-15, 1850.

Rodrigo, F. S., Esteban-Parra, M. J., and Castro-Diez, Y.: The onset of the little ice-age in Andalusia (Southern Spain) Detection and characterization from documentary sources, Ann. Geophys., 13(3), 330-338, 1995.

Rodrigo, F. S, Esteban-Parra, M. J., Pozo-Vazquez, D., and CastroDiez, Y.: A 500-year precipitation record in Southern Spain, Int. J. Climatol., 19(11), 1233-1253, 1999.

Rodrigo F. S. and Barriendos M.: Reconstruction of seasonal and annual rainfall variability in the Iberian peninsula (16th-20th centuries) from documentary data, Global Planet. Change, 63, 243-257, 2008.

Saz, M. and Creus-Novau, J.: La variabilidad del clima español en el pasado: frecuencia de valores extremos de temperatura y precipitación trimestrales reconstruidas desde el siglo XV, in: La climatología española en los albores del siglo XXI, Oikos-Tau, Asociación Española de Climatología, Barcelona, Spain 501510, Serie A, Nr. 1, 1999.

Saz, M. A.: Temperaturas y precipitaciones en la mitad norte de España desde el siglo XV. Estudio dendroclimático, Consejo de Protección de la Naturaleza, Diputación General de Aragón, Zaragoza, Spain, 2003.

Skazkin, F. D.: The critical period in plants as regards insufficient water supply, Timiryazevskie Chteniya Akad, Nauk SSSR 21, $1-51,1961$.

Sousa, P., Trigo, R. M., Aizpurua, P., Nieto, R., Gimeno, L., and García-Herrera, R.: Trends and extremes of drought indices throughout the 20th century in the Mediterranean, Nat. Hazards Earth Syst. Sci., accepted, 2010.

Tebaldi, C., Hayhoe, K., Arblaster, J. M., and Meehl, G. A.: Going to the extremes: An intercomparison of model-simulated historical and future changes in extreme events, Climatic Change, 79, 185-211, 2006.

Trigo, R. M. and DaCamara, C. C.: Circulation weather types and their influence on the precipitation regime in Portugal, Int. J. Cli- 
matol., 20, 1559-1581, 2000.

Vicente-Serrano, S. M.: Spatial and temporal analysis of droughts in the Iberian Peninsula (1910-2000), Hydrolog. Sci. J., 51, 8397, 2006a.

Vicente-Serrano, S. M.: Differences in spatial patterns of drought on different time scales: an analysis of the Iberian Peninsula, Water Resour. Manag., 20, 37-60, 2006b.

Vicente-Serrano, S. M. and López-Moreno, J. I.: The influence of atmospheric circulation at different spatial scales on winter drought variability through a semi-arid climatic gradient in northeast Spain, Int. J. Climatol., 26(11), 1427-1453, 2006.

Vicente Serrano, S. M. and Cuadrat, J. M.: North Atlantic oscillation control of drought in north-east Spain: evaluation since 1600 A.D., Climatic Change, 85, 357-379, 2007.
Villar y Macias, M.: Historia de Salamanca, Imprenta de Francisco Núñez Izquierdo, Salamanca, Spain, 1887.

Von Storch, H., Zorita, E., and Cubasch, U.: Downscaling of climate change estimates to regional scales: An application to iberian rainfall in wintertime, J. Climate, 6, 1161-1171, 1993.

Wilhite, D. A. and Glantz, M. H.: Understanding the drought phenomenon: The role of definitions, Water Int., 10, 111-120, 1985.

Zamora, R.: El final de la pequeña edad de hielo, Publicaciones Universidad de Alicante, Alicante, Spain, 2002.

Zwiers, F. W. and Kharin, V. V.: Changes in the extremes of the climate simulated by CCC GCM2 under CO2 doubling, J. Climate, 11, 2200-2222, 1998. 